\title{
OBSTACLES TO THE INTRODUCTION OF EFFICIENT MONEY INCENTIVES IN A HUNGARIAN FACTORY
}

\author{
LAJOS HÉTHY and CSABA MAKÓ
}

\begin{abstract}
A PREVAILING belief in Hungarian society is that through the decentralization scheme for the centrally planned economy introduced in 1968, most obstacles to the growth of industrial efficiency can be overcome, directly or indirectly, by differential money incentives. For the past three years a part of company profits has been used for differential incentive bonuses: up to 80 percent of salary for top management, 50 percent for middle managers, and 15 percent for wage earners. This considerable share in profits has seemed to be a driving force for management; managers have made manifold attempts to increase efficiency and profits in their companies. However, they usually have failed in their efforts to get workers to
\end{abstract}

Worker productivity can not be improved simply by introducing a system of money incentives. Production difficulties have their origins in the divergent interests and powers of various groups within the work establishment and require complex modifications of the social and economic environment for their solution. This study of a Hungarian factory points up the need to identify the various groups of participants, the conditions under which they are motivated to produce, and the processes by which multiple centers of interests and power develop. It concludes that resolution of socioeconomic conflicts is essential to achieving satisfactory work performance.

Lajos Héthy and Casba Makó are members of the Institute of Sociology, Hungarian Academy of Sciences.-EDITOR make a greater contribution to company objectives; obstacles to the growth of efficiency have continued to exist on the shop floor.

As a general rule, labor has rejected company goals; there has remained a constant gap between the targets set by management and the day-to-day performance of employees. Lack of sympathy with management's objectives has been manifest in many ways: workers have resisted attempts to maintain strict discipline, they have deliberately restricted output, they have performed work of poor quality, and so forth. Many managers and economic leaders believe that this discrepancy between company goals and labor's behavior can be attributed to inadequacies in money incentives, that is, to the lack of fair wage differentials among workers.

Our proposition is that the causal relations are not so unambiguous and simple: inadequacies in wage incentives, although closely connected with difficulties in the workshops, cannot be a basic cause of discipline problems and restriction of output, but themselves are also a symptom. The underlying cause of the difficulties, including the lack of fair wage differentials, lies in the structure of interests and powers within the organization and is based on certain micro 
and macro factors in the social and economic environment. These factors originate from the present regulations set up by social and economic central agencies and from the characteristics of the overall socioeconomic system of industry which has come into existence as a result of developments of the past few decades.

To place our proposition in a sharper focus: production difficulties in workshops cannot be solved solely by revision of the incentive system. The solution of these problems, including the introduction of efficient wage differentials, requires complex changes in the structure of interests and power within the enterprise, that is, complex modifications in the social and economic environment.

\section{The Company, Its Workers, and Shop-Floor Problems}

Our proposition is supported by the results of a sociological survey carried out in an engineering factory in western Hungary. The company to be discussed plays an important role in the economic activity of the country. It manufactures railway coaches, tank wagons, differential gears, axles, steering gears, and chassis for trucks and buses-mostly for export. It also has started production of heavyduty Diesel engines under license from a West German firm. In its different units the company employs a total of about fifteen thousand production workers.

The unit in which the survey took place manufactures bodies for railway coaches. Its employees, about two hundred sheet-metal workers and welders, work in groups organized by the nature of their tasks. The work groups are paid on the basis of how much they produce, according to a straight piece-rate system. As a group's productivity increases, its earnings also rise; and conversely, as output falls, there is a corresponding drop in earnings. Within the group, earnings are not divided equally but on the basis of the personal wage rates of the members. The wage plan thus is designed to function as a group incentive and as an individual incentive at the same time. The activities of the groups are directed by nine foremen and two senior foremen.

The management of the company was not satisfied with discipline and work intensity in the railway coach unit, as individual workers and even groups often restricted output and had high turnover rates, thus endangering the continuity of production. For this reason, management revised the wage plan in 1968. The revision was based on a widespread belief that setting proper wage differentials would provide the solution to production problems. ${ }^{1}$

The wage plan, as a group incentive, seemed to be satisfactory. As an individual incentive, however, it seemed to be unresponsive to management's efforts to enlarge the quantity of output. Personal wage rates, which regulated the relations of individual earnings within the group, had been set according to a central service and merit-rating system. The favorite factors of the system, length of service in the company and professional qualification, were irrelevant to individual output, since neither long experience nor high-skill qualification were needed in the highly routinized work in the plant. Thus, the system of personal wage rates had two major deficiencies: (1) wages did not properly reffect indi-

${ }^{1} \mathrm{~A}$ system of differential incentive bonuses was introduced in Hungary in 1968 as a national scheme. It was part of a series of economic reforms intended to produce a decentralized and more flexible industrial structure, with increased emphasis on market requirements and efficiency. 
vidual effort and yielded different earnings to workers of equal performance; and (2) the scale of individual wage differentials, originating from the rates, did not reflect possible differences in individual output, because it was too narrow.

To correct these inadequacies, management abolished the central service and merit-rating system and authorized the foremen and the work groups, as the persons having the most accurate information about the efforts of individuals, to set new personal wage rates. The new rates set by the foremen and workers were, however, even less responsive to management's objectives than the previous ones. Individual wage inequities continued to exist, and the range of individual wage differentials became even narrower. ${ }^{2}$

In the course of our survey, we examined the empirical and logical connections among the level and scale of individual wage differentials approved by the employees, the structure of interests and powers within the organization, and the socioeconomic environment. Our survey endeavored to cover all the important factors motivating the behavior of workers and foremen. The information needed came from three sources: (1) structured interviews with each worker in the unit, with the help of a substantial questionnaire; (2) unstructured interviews with the majority of workers, with the foremen, and with representatives of top management; and (3) data in the records of the company.

\section{Need for Labor-Management Cooperation}

The long-run economic success of a business organization requires coopera-

${ }^{2}$ The coefficient of variation of the original scale was 0.13 , that of the revised scale 0.10 . tion between the two major participants in production, managers and workers, and the formation of company goals acceptable to both. Cooperation and working out common goals can be based only on the solution of conflict situations produced by divergencies in the interests of management and labor and on the existence of compromise situations, in which the two major participants have a relatively good bargain in comparison with their contributions to the success of the organization. Compromise, however, does not develop automatically from conflicts; a certain balance of power and influence is necessary between management and labor to advance the process.

In the case of the company examined, cooperation between managers and workers was not satisfactory. The employees rejected the goals which the employers had prescribed for them. Conflict situations seemed to be lasting, and the equilibrium of opposing powers appeared to be upset.

On the assumption that the structure of interests and powers is determined by the social and economic environment, we examined all factors which might have a direct or indirect effect on the interests, goals, influence, and behavior of people within the framework of the organization. As the company is part of a centrally planned economy, we paid special attention to regulations by the central agencies.

\section{Divergence in Management and Worker Goals}

The clashes between the interests of management and labor focused on wages and output. Management, stimulated by its considerable share in profits, using prices in the international market as a guide, tried to choose a profit-maximiz- 
ing bundle in its production-possibility set. (Plant managers have had remarkable freedom in such decisions since the introduction of decentralization in 1968.) The decision was made to withdraw from manufacture of railway coaches and undertake production of heavy-duty Diesel engines for buses and trucks. The company's antiquated technology for railway coach manufacture made the operation unprofitable, and state subsidies were being withdrawn. In addition, demand for coaches is limited and several other companies produce them under more favorable circumstances. However, immediate cessation of production was not possible; withdrawal was to take the form of a gradual reduction of production. Accordingly, management felt that cuts in production costs were necessary. Since investment in new equipment or processes was not indicated under the circumstances, management decided to cut labor costs by decreasing wages per unit of output.

Labor, as its share in profits was low, was motivated by wages. Workers were ready to make extra efforts for extra pay and aimed their activities at maximizing earnings. The employees in the workshops, mostly of agricultural origin, were hard-working people, in whose thinking wages were fundamental in relation to their families' living standards and also as a measure of their importance in relation to others in and out of the factory. The workers, consequently, opposed the managers' goals, regarding them as directed at "sweating" labor simply to "fill the company coffers."

\section{Central Wage Regulations}

Responsibility for the divergence of management and labor interests cannot be fixed, however, entirely on the profit- sharing system, on the high level of production costs, on backward technology, or on the withdrawal of governmental subsidies. A prominent part was played in the continuing confrontation by the control of central agencies over the level of wages. The central regulations pegged wages per capita on a roughly equal level in all engineering companies owned by the state. Any increase had to be covered from the share of profits to be divided among the participants in production, a sum that was considerable in relation to the salaries of managers but extremely small in relation to the total amount of wages of employees. Thus the management made attempts to cut wages per unit of output and at the same time to keep wages per capita unchanged; it required extra effort from its employees without being willing or, in fact, capable of giving them extra reward. ${ }^{3}$

Only on the basis of the conditions of the company and the specified rules the management was obligated to follow, can we understand the contradictory features of its incentive policies. Management pressed the work groups for increased production and, to this end, employed an efficient group incentive, a piece-rate system without (at least, theoretically) any ceiling on earnings. It promised extra reward for extra output. Moreover, as we have noted, management also made attempts to improve in-

${ }^{3}$ The control of central agencies over wages was intended to avoid certain undesirable effects of the economic reform. Total freedom of managers, motivated by their share in profits, to regulate wages might have led to rapidly growing earnings for some workers, while causing unemployment for others, and/or to a high rate of inflation and disequilibrium of supply and demand in the market for consumer goods. Such a process would have been followed by sharp and open social conflicts instead of the concealed ones described in this article. 
Table 1. Worker Evaluation of Possibilities Offered by Work for Self-Improvement and Self-Expression Compared to Worker Desires.

\begin{tabular}{ccccc}
\hline & $\begin{array}{c}\text { Learning } \\
\text { New Things }\end{array}$ & $\begin{array}{c}\text { Using One's } \\
\text { Own Ideas }\end{array}$ & $\begin{array}{c}\text { Doing } \\
\text { Interesting Tasks }\end{array}$ & $\begin{array}{c}\text { Making Use of } \\
\text { One's Professional } \\
\text { Knowledge }\end{array}$ \\
\hline Actual situation & 1.40 & 1.70 & 1.58 & 1.95 \\
Desired situation & 2.50 & 2.39 & 2.90 & 2.74 \\
Gap & -1.10 & -0.69 & -1.32 & -0.79 \\
\hline
\end{tabular}

The indexes represent the averages of evaluations given by about two hundred workers. A score of 3.0 means a high possibility, while a score of 1.0 means no possibility.

dividual incentives by revising the service and merit-rating system. But when work-group productivity and earnings rose appreciably, it arbitrarily reset piece rates, also cutting wages per capita and pegging them to the level permitted by the central agencies. In 1969, piece rates were cut twice, resulting in a 20 percent loss for labor in wages. ${ }^{4}$

\section{Worker Perceptions of Their Jobs}

Labor-management conflicts over the level of wages were of the utmost gravity, as wages held a top place in each worker's evaluation of his job. Workers told us: "We do not come here to produce railway carriages, but to earn a living." The reasons for the money-centered attitude of labor can be found partly in the present level of living in the country and partly in aspects of the environment which hinder the satisfaction of higher-

'The regulations of the central agencies do not necessarily call into existence such management policies. In several engineering companies, poor standards, poor scheduling of jobs, insufficiencies in the supply of material and in the maintenance of tools automatically prevent management from building up workable incentive systems. Managements in other firms, enjoying large subsidies and favorable internal market conditions set by the central agencies, naturally refrain from pushing workers to increased effort. In all these cases, a tacit agreement is forced on labor by management; management does not offer extra pay and does not require extra work either. level needs of individuals within the factory. Working people were frustrated by the monotony of their routinized jobs, by their inability to advance professionally, by the pressures to which they were subject as they tried to do work of quality instead of quantity, and by their inability to achieve a measure of respect and autonomy in their everyday activities.

Table 1 presents a summary of worker responses to a questionnaire asking them to indicate the extent to which they felt the actual work situation offered possibilities for self-improvement and selfexpression. If a worker felt his job offered very good opportunity for learning new ideas or skills, his response was scaled at 3.0. If he felt it offered no possibility for learning new things, his response was marked 1.0. The "desired situation" represents the aspirations of the respondents, that is, the extent to which they would like to have opportunities for learning, using their own ideas, doing interesting tasks, or using their professional knowledge.

The workers had practically no chance for promotion to the positions of foreman and senior foreman, posts usually within the limits of workers' career structure. On the one hand, in the unit to be shut down the number of such positions gradually was decreasing; on the 
Table 2. Workers' Evaluation of Role Actually Played in Promotion by Various Factors as Compared to Their Perceptions of Desirable Role.

\begin{tabular}{ccccccc}
\hline & Individual & Company & Professional \\
Performance & Service & Knowledge & $\begin{array}{c}\text { Approval } \\
\text { by Fellow } \\
\text { Workers }\end{array}$ & $\begin{array}{c}\text { Friends } \\
\text { in Top } \\
\text { Management }\end{array}$ & $\begin{array}{c}\text { Social/Trade } \\
\text { Union and } \\
\text { Party/ } \\
\text { Functions }\end{array}$ \\
\hline $\begin{array}{l}\text { Actual situation } \\
\text { Desirable situation }\end{array}$ & 1.88 & 2.01 & 2.13 & 1.39 & 2.11 & 2.13 \\
Gap & 2.34 & 2.28 & 2.50 & 2.32 & 1.07 & 1.31 \\
\hline
\end{tabular}

The indexes represent the averages of evaluations given by about two hundred workers. A score of 3.0 means a significant role, while 1.0 means an insignificant one.

other hand, promotion in the company was based in large part on factors unrelated to skill or experience such as informal links to management, party membership, and trade union activities. Workers' perceptions of the role played in promotion by various factors as compared to the importance they felt should be given these factors are presented in Table 2. Because of lack of satisfaction of their higher-level needs, workers sought compensation in money.

\section{Role of the Union}

The series of management victories and labor defeats, good bargains on one side and poor bargains on the other, resulted in a lasting confrontation, the existence of which reflected a lack of equilibrium in power, an imbalance of opposing forces at the company. The management wielded an overwhelming power which the trade union, destined to defend the interests of labor, was incapable or unwilling to counterbalance. Incentive policies at the company, including the continual cuts in piece rates, were approved by the executive of the trade union. The union, a heritage of a previous period, united in its ranks all sorts of members of the business organization, from unskilled workers to top managers. Several trade union positions were occupied by foremen, middle managers, and even top managers. The union's executive had a considerable share in company profits. In fact, top union leaders and top company managers, despite occasional spectacular confrontations, seemed to the workers to be a monolithic group.

Although labor's rights to take part in company affairs, including decisions about the wage plan and promotion, were guaranteed, workers had no means to implement them. The functioning of the institution of workers' direct participation in management decisions relevant to their interests proved to be profoundly formal. The dominant push from labor might have come through the informal organization of workers, which sometimes had substantial powers rival to those of management, but in most cases this informal organization was weak.

It has been suggested that the core conflict is between management and labor and arises from certain micro and macro economic and social factors, created by the present regulations of the central agencies and by the realities of the socioeconomic progress of past decades. On the assumption, however, that people generally act under the influence of their environment, it seems obvious that neither company managers nor fac- 
tory workers are homogeneous social units. Both are divided into several strata representing divergent interests and goals. Thus the next step of our study was to scrutinize the intramanagement and intralabor structures of interests and powers, which affect harmony within the company.

\section{The Structure of Management}

Within management, the foremen and other lower-level supervisors formed a separate stratum, with objectives often contradicting the interests of top managers. These "men in the middle" had substantial power to influence the production and wages of work groups. The functional departments of management were incapable of controlling production problems, including supply of material and maintenance, and their solution was up to the foremen. (This situation originated in the primitive level of technology, characteristic of the small factories of the past.) But top managers, believing in the efficiency of centralization within the company, did not take into consideration the influence of the foremen. Accordingly, nothing had been done to insure their cooperation. Foremen received salaries inferior to those of the best-paid workers, and this state of affairs remained unchanged regardless of their special efforts or negligence. As a result, management policies were a matter of indifference to foremen. They neither aided nor hindered the success of management's attempts to encourage work group and individual output but restricted their activities to the performance of routine tasks. Their substantial powers remained largely potential, and their role in the discussions between top management and labor was of minor importance.

\section{Separate Strata in Labor}

Labor was also divided into separate strata. Each worker considered management's incentive policies hostile to his interests and protested efforts to cut labor costs. Workers' devotion to money was general. However, personal wage rates, seniority with the organization, professional skills, household expenses, structure of consumption, traditions, and other factors produced a compartmentalization within the labor group similar to that which occurred at management level. There were two major factors responsible for the division of workers into strata with divergent interests and various powers.

1. The current level and the future prospect of the individual's earnings, that is, his actual and expected economic position in the organization. Both were dependent on wages per capita in the work group to which the individual belonged and on his personal wage rate. As wages per capita were pegged by the company on roughly the same level in all the groups, differences in the actual and expected economic positions could be caused only by personal wage rates. These rates, set primarily on the basis of length of service in the company or job experience, moved rapidly upward until age thirty and then stopped. As a result, workers above thirty years of age earned a relatively good living, while their fellow workers below thirty were doing rather poorly. But the reverse of the medal was that workers over thirtyyears old had no prospects of further wage increases, and management policies put them in a hopelessly deteriorating position, while younger workers enjoyed rapidly growing wages and, in this way, were partly compensated for losses caused by piece-rate cuts. 
2. The style of living of the worker and his family. This factor is closely connected with the previous one, as the main source of a worker's income is his earnings. People over thirty-years old usually had a well-balanced household budget. They generally had their own homes, well-furnished and mechanized. They had ended debts connected with building or purchasing their homes and had acquired durable goods such as television sets, refrigerators, washing machines, and motorcycles. To the earnings of the head of the family, the earnings of the wife were added. She also might have a job as their children had reached school age. Workers below thirty years, on the other hand, carried the burdens of fundamental investments connected with the establishment of family life. They were indebted to the savings bank for money to build or buy a house and to furnish it. Moreover, as their children were small, their wives usually could not take a job. (In the differences of the economic positions of families, a dominant role was played by the housing shortage in the country, which exerted a strong pressure on household budgets for several years in the worker's life.)

On the basis of these and other economic factors, workers were divided into two major strata with divergent interests and various powers. The age of thirty seemed to be the economic (not demographic) dividing line.

\section{Different Attitudes Toward Performance}

Workers above thirty years of age vigorously resisted management's efforts to secure maximization of production by the work group. Instead, they were in favor of the optimization of group output. Optimization meant temporary maximization to exploit the upward trend of production and wages stimulated by management, followed by a temporary slowdown to avoid piece-rate cuts so as to avoid jeopardizing earnings. Their objective represented a form of rational accommodation to the contradictory features of management's incentive policy and also was based on consideration of the state of their household budgets. Slowdowns and the accompanying drops in earnings connected with optimization were made possible by the flexible needs of these older workers for money, by their relatively high earnings within the organization, and by the sound economic position of their families.

Because workers under thirty years, on the other hand, had no alternatives to choose among, they acted almost entirely under the economic pressure of their positions. Their needs for money were inflexible as a result of their relatively low individual earnings and the expenses of their household budgets. Though reluctantly, they met management's demands to maximize work-group performance. They aimed their activities at extracting the most possible money from the company, regardless of the consequences.

The power of the two strata of labor, clashing within the framework of the group, was not equal. The older workers (over thirty years) had built up an extended informal organization and occupied nearly all formal positions of power in many work groups. The existence of their informal organization, based on the compromise of fairly flexible individual interests, originated from the members' being cornered by management and, in a sense, by younger workers as well. People under thirty years usually had less power and were subject to greater pressures from their family 
Table 3. Work Groups Classified by Behavior and Attitudes Concerning Performance and Personal Wage Differentials.

\begin{tabular}{ccccc}
\hline Type of Group & Number of Groups & $\begin{array}{c}\text { Behavior in } \\
\text { Job Performance }\end{array}$ & $\begin{array}{c}\text { Wage Differentials Approved by Group } \\
\text { Level }\end{array}$ & $\begin{array}{c}\text { Index* } \\
\text { L }\end{array}$ \\
\hline I & 10 & Optimization & Medium & .09 \\
II & 5 & Maximization & High & .13 \\
III & 4 & Maximization & Very low & .01 \\
\hline
\end{tabular}

*Coefficient of variation.

Table 4. Socioeconomic Backgrounds of Work Group Members.

\begin{tabular}{ccccccc}
\hline \multirow{2}{*}{ Type of Group } & Skilled & $\begin{array}{c}\text { Percentage of Each Type } \\
\text { Service Over } \\
\text { Ten Years }\end{array}$ & $\begin{array}{c}\text { Family } \\
\text { Heads } \\
\text { Thirty }\end{array}$ & $\begin{array}{c}\text { Own } \\
\text { Home }\end{array}$ & $\begin{array}{c}\text { Average } \\
\text { Personal } \\
\text { Wage Rate } \\
\text { forints }\end{array}$ \\
\hline I & 65.1 & 80.3 & 53.0 & 77.7 & 60.8 & 8.35 \\
II & 32.8 & 78.2 & 25.2 & 51.5 & 32.8 & 7.85 \\
III & 84.3 & 50.5 & 41.1 & 73.7 & 78.9 & 8.23 \\
\hline
\end{tabular}

positions and forces within the factory. The pattern of conflicting interests and powers within labor, which the managers tried successfully to exploit on the principle of divide et impera, had an effect also on the sharpness of the overall confrontation between employers and employees. Labor, torn by internal clashes, was unable in most cases to build efficient resistance against management, and that made a considerable contribution to the permanence of chronic disagreement.

\section{Patterns in Behavior of Work Groups}

Work groups showed significant differences in attitudes and behavior concerning performance and personal wage differentials. They could be classified in this respect into three types, as is done in Table 3.

Work groups belonging to the three types differed in skill, length of service with the company, family status, and other socioeconomic characteristics, as indicated in Table 4 . All included workers in the older and younger age groups but in different proportions.

\section{Type I Groups}

The great majority of members of groups in Type I were older workers (over thirty years), while younger persons were in the minority. The older workers joined together to build a powerful informal organization, including 70 percent of group membership. They seized all possible sources of formal power, occupying the positions of group leaders and trade union functionaries. There were also several Communist party members among them.

The informal organization served as an agency through which members obtained and evaluated information about their environment. It worked out normative rules for collective activity in order to control the aspects of economic and social environment which were of consequence to individual members. It func- 
tioned as a defense, endeavoring to protect its members and to extract the most possible for them from their common enemy. It carried out the policy of optimization of work-group productivity, combating deterioration of the economic positions of workers and keeping their wages, in comparison with their efforts, at a maximum.

Younger workers (those below thirty years) were isolated individuals, outside the framework of the informal organization. They were forced, by the substantial power of the older people, to agree to optimization of output. Although it did not always suit their interests because of their inflexible and pressing needs for money, they could perceive its advantages and worked in relatively peaceful coexistence with the others.

The members of the informal organization, although a decrease in individual wage differences contradicted their immediate interests, set personal wage rate differentials on a medium level (.09 index). In this way they made a concession to the younger workers to insure better cooperation within the work group against management. Groups in Type I, due to their highly developed centralized informal organization, were capable of counterbalancing, to a remarkable extent, the power of the management. Sometimes they successfully undermined management attempts directed against them, other times they suffered defeats; but they never capitulated. As the result, they usually lived in a peaceful atmosphere in the organization. Some groups, owing to their extraordinary cohesiveness and to their monopolistic position in the process of production, even managed to attain very high average earnings, far above the level pegged by the company.

\section{Type II Groups}

The membership of work groups of Type II was made up of a majority of younger workers and a small minority of older people. Informal organization was weak and divided into opposing units, as both the older and younger workers created their own informal bonds of solidarity to protect their interests. At the same time, the means of formal power also were divided between the two strata: both occupied group-leader, tradeunion-functionary, and Communist-party positions. Older workers, however, as they were in a minority and their powers proved to be weak, were forced to give up their original objectives and surrender to the maximization of output urged by their younger fellow workers and by management. This capitulation resulted in a permanent deterioration of their position, caused by continual piece-rate cuts. Thus, confrontation in a rather sharp form became lasting within the groups in Type II.

The high-level individual wage differentials (.13 index) can be explained on the basis of these intragroup clashes. Workers over thirty-years old were unwilling to concede to the younger people on wage differentials, as cooperation against management was not possible. They were fighting, in this case with considerable success, to preserve a high level of personal wage-rate differentials favorable to them. The work groups, torn by internal struggles, could not counterbalance the power of management. The older workers, brought to bay by their cohorts, suffered painful defeats from continual piece-rate cuts, while younger people-though somewhat compensated by the growth of their personal wage rates-also were hurt. 


\section{Type III Groups}

The members of work groups in Type III belonged to the strata of older workers, whose best interests, under the circumstances of the company, required the optimization of output. This form of self-defense was made impossible, however, by certain factors in the physical and economic environment not previously mentioned. The simple preparatory operations in the unit were performed by these groups, while workers in the other groups were engaged in the more complicated building of the railway carriage's body. The existence of a group incentive in Types I and II was justified by the collective nature of work, while in the Type III groups it was introduced to simplify administration. The workers, only a few in number, performed their tasks separated from each other in the different corners of the shop and in shifts. The nature of work and the lack of permanent collective activities kept members from forming the strong informal bonds which were essential for the optimization of output. Furthermore, wages per capita, on a roughly equal level in all the other groups, here were kept very low by management as a result of the simple individual tasks. Under the pressure of these circumstances, the only choice for the Type III groups was the maximization of productivity. Over time, these workers were forced to make an increasing contribution to company objectives for nearly the same amount of money. As a primitive form of defense, they decreased differences in personal wage rates to a minimum (.01 index).

The various types of work-group behavior in performance and in setting wage differentials were thus derived from the structure of interests and powers within the work force (intralabor rela- tions) and within the company (labormanagement relations), based on the whole of the socioeconomic environment. The various types of work-group behavior resulted in different outcomes: some work groups managed to reach exceptionally high wages beyond any limits set by the company or by the central agencies; others fared poorly. Some work groups carried out their activities at a comfortable pace, others struggled under the pressure of tight piece rates.

The findings of this examination of work-group behavior and intralabor and labor-management relations are summarized in Table 5.

\section{Conclusions}

The findings of this study seem to support rather convincingly the proposition initially proposed: difficulties on the shop floor, including the inadequacies of the incentive system, have their basic cause in the structure of divergent interests and various powers within the company. The decrease in individual wage differentials carried out by labor in opposition to management's goals, the occasional deliberate slowdown of production by a significant number of work groups and the high mobility of manpower, all are symptoms of labor-management and intralabor conflict situations and of a disequilibrium of power. In this respect, the indexes of mobility are worth noting. In Type I work groups, where tension was relatively low due to the considerable power of the workers, only 21 percent of members left the company during one and one-half years. In Types II and III, where confrontation was especially sharp owing to the defenseless situation of certain strata, about 60 percent of workers gave warning to the firm in the same period. 
Table 5. Piece Rates, Intralabor Relations, and Labor-Management Relations by Types of Groups.

\begin{tabular}{|c|c|c|c|}
\hline & $I$ & $\begin{array}{c}\text { Type of Group } \\
\text { II }\end{array}$ & III \\
\hline Level of piece rates & loose or normal & normal or tight & very tight \\
\hline \multicolumn{4}{|l|}{ Intralabor relations: } \\
\hline Structure of interests & $\begin{array}{l}\text { workable compromise } \\
\text { between two strata }\end{array}$ & $\begin{array}{l}\text { chronic conflicts } \\
\text { between two strata }\end{array}$ & no definite structure \\
\hline Structure of power & $\begin{array}{l}\text { central, powerful } \\
\text { informal organization }\end{array}$ & $\begin{array}{l}\text { divided, weak } \\
\text { informal organization }\end{array}$ & $\begin{array}{l}\text { only casual informal } \\
\text { bonds among members }\end{array}$ \\
\hline \multicolumn{4}{|l|}{ Labor-management relations: } \\
\hline Structure of interests & low level of conflicts & high level of conflicts & high level of conflicts \\
\hline Structure of power & $\begin{array}{l}\text { relative equilibrium } \\
\text { of power }\end{array}$ & $\begin{array}{l}\text { permanent disequi- } \\
\text { librium of power }\end{array}$ & $\begin{array}{l}\text { complete defenseless- } \\
\text { ness of workers }\end{array}$ \\
\hline
\end{tabular}

The structure of powers played an especially important role. The lack of proper division of the means of power among the participants in production produced very serious consequences. It also seemed that not only was the division of power imperfect, but also the total amount of power at the disposal of the organization was insufficient. The company seemed to be too tied by central regulations to be capable of finding satisfactory solutions for its pressing problems. The constructive participation of labor scarcely can be anticipated, if management itself does not have enough freedom in making vital decisions (for example, concerning the level of wages).

As the structure of interests and powers is determined basically by the socioeconomic environment, the difficulties in the workshops can be overcome only by coordinated fundamental modifications in the complex of micro and macro socioeconomic factors. The prevailing belief in Hungarian society that problems regarding the attitude of labor can be solved by the revision of incentive plans and the introduction of fair-wage differentials, that is, by change in a single microeconomic factor, is profoundly naïve, as proved by the example of the company studied. The major factors influencing the course of events within the factory are the following:

1. Macro (that is, national) measures include the regulations of the central agencies of the economy, such as the profit-sharing system, the control over wages per capita, the practice of setting prices for the internal market and of giving subsidies to business organizations, the system of credits for company investments, in brief, the decentralization scheme of the centrally planned economy introduced in 1968. One also can include here regulations directly affecting labor: the central measures directed at the welfare of the population (the social insurance system, the housing program, the policy of taxation, and so forth). Rules outlining the organization and functioning of social institutions like trade unions also should be mentioned. The central regulations are based on scientific analysis of the economic and 
social realities of the past several decades and include complicated social, humanitarian, and political preferences. That is why their change, although required by a number of negative side effects, cannot be a rapid process.

2. Micro (company) measures include management incentive policies (the overall wage plan, the system of personal wage rates, incentives for foremen and other middle managers, the method of piece rate setting, and so forth), promotion policies, the functioning of trade union and other social organizations, the decentralization of internal decisions, the construction of institutions for labor's participation, the existence and stability of informal organization, the social composition and stratification of workers, the effects of their out-of-factory environments and traditions, and so forth.
Although all these micro factors are closely connected with the macro ones, certain improvement in the solution of conflict situations can be achieved even by their revision within the limits of the company's possibilities, if the modifications are based on careful consideration.

The following forward step, however, requires the contribution of social science. Much more emphasis should be placed on defining the main groups of participants and the conditions under which they are motivated to participate and to produce, on the processes by which multiple centers of power and influence develop, and on conflict resolution as a subject which is important not only in labor-management relations but also in most other intergroup relations within the firm as well. 